\title{
Book Review: Water Politics: Governance, Justice, and the Right to Water edited by Farhana Sultana and Alex Loftus
}

\author{
Naimah Talib ${ }^{1,2, *}$ \\ 1 School of Geography, Earth, and Atmospheric Sciences, Faculty of Science, the University of Melbourne, \\ Australia \\ 2 Visiting Researcher at the Indonesia Science Institute (LIPI) \\ * Correspondence author: ntalib@student.unimelb.edu.au
}

Water Politics: Governance, Justice and the Right to Water ( $1^{\text {st }}$ Edition) Edited By Farhana Sultana and Alex Loftus, ISBN 9781138320031 , Published 2019 by Routledge, 238 Pages.

Water is essential to human and living beings both for its physical and non-physical forms that enable humans to function. This book broadens discussions about water, from its physical dimensions and its use to beyond-physical ontological forms of water. The authors show that water is situated as a crucial part of social, cultural, and spiritual beings. Departing from the ontological pluralism of water, water has become more contested, not only as a commodity that is inseparable from the well-functioning of human lives but also as part of the living ecosystem. This book, not only deepens such frames of analysis but also advances recent debates around water bodies/ rivers/ oceans as having a right in and of itself as part of the multispecies living being in a shared space of planet Earth. Further, this book contributes to re-centering water as a fundamental environmental justice issue. This book contributes to the debates around the recognition aspects of justice, which makes claims for acknowledgement of different sets of values and cultural practices underlying valuation of water, which are often dominated by materialistic values. As Linton suggests on page 63 'No amount of citizen participation, social learning or stakeholder involvement in decision making process is likely to resolve the problem of different waters realised through different practices... without recognition of different political ontologies."

This book provides a structured means for not only responding to the political and social problems in realising the right to water, but also its meta-political representation (formation of its very framings) (Fraser, 2009), of which we are allowed to claim for justice. Water Politics: Governance, Justice and the Rights to Water asks "how far have we made progress in realising [the] right to water? And under what frames are these policies and practices operating?". This book discusses a broad range of topics from the politics of water and water governance, human rights to water, and engages with water through the capabilities framework, addressing key issues around the water-food security nexus, water justice, and the intersectionality of water in varied contexts of the Global South and Global North, bridging urban and rural areas.

The book highlights the evolving political ontologies of and about water across temporal, spatial, and governing scales, and how interpretations of such plural conceptions have been realised so far. The editors compiled various papers highlighting the progress that has been made in delivering and claiming rights to water across geographical-spatial contexts in the past three decades. The authors adopt a critical geography approach to water, and each of the fourteen articles present deep observations and critical analysis of empirical cases. While Linton's contribution in particular, entitled 'The rights to bring waters into being', engaging in a more theoretical debate on contesting the dominant political ontology of water in a globalised capitalist society and its 
implications to the (lack of) realisation of rights to water for indigenous communities. Most of the articles are linked to place-based frames of analysis, exploring political economy phenomena connected to global development agendas. They contribute to the importance of systems-level analysis, or as some scholars describe as 'political-ecological' analysis or relational analysis (Barnett and Campbell, 2010; Sultana, 2014; Barnett, 2001). Such an approach helps us better understand the nature of contestation of access to and control over water. This book manages to deliver its key argument that as the conceptions of water(s), its being, and its uses, grow, the interpretations of how to treat, govern, use, and control it, to achieve the 'right to water', also evolves. This book, thus suggests for a critical and careful-celebratory approach in evaluating the realisation of the right to water as one of the central global development questions.

Water Politics are wrapped up within the ongoing and emerging conversations around water in scholarly and policy debates across the globe, which also highlights the relevancy of such a book. For instance, Anna Walnycki engages on water in informal settlements in Bolivia (pp. 99-112), which has also been observed in Jakarta and other urban contexts in Indonesia, whereby communities and NGOs attempt to create political, social, and technological space in advancing access to 'affordable' water (Kooy, 2014; Kooy and Bakker, 2008). Meanwhile the ethics, morals, and the politics around the use of bottled water (Raul Pacheko-Vega, pp.113-128) is also closely related to events around the Palu tsunami, and other disasters events, in Indonesia. Bottled water as an emergency provided relief on the one hand in terms of access to clean water as something essential for human survival, but the plastic waste and over-dependency on 'outsider donors' raises questions over sustainability and the overall support system itself. The rights to water in the context of sanitation is also raised in an intersectional lens (Patrick Bond pp. 189-202), an emerging area of empirical engagement that can be applied to other cases, whereby access to clean water and sanitation in a neoliberal-policy deliberation agenda remains a serious justice issue that needs to be addressed in many contexts. In many places, women and young girls are responsible for providing clean water for the family, including if they have to walk for miles, in often unsafe environments (Sultana, 2014; Bessell, 2015; Lahiri-Dutt and Samanta, 2013). Andreas Bieler (pp. 129-142) and David A. McDonald (pp. 143-160) highlight the struggles to put 'rights to water' in the central debate of policymaking at the nationstate and municipal level while questioning the highly technical-solutions promoted to solve water issues, which often depoliticizes them and are uncritically free of moral-judgment. These papers, among other contributions from the book, are not only relevant to other localities and communities, but also echo emerging research engagement in other contexts.

What makes this book refreshing is, first, it summarizes the various key debates in an increasingly globalized world in an era of neoliberalism. Without undermining rights-based to water, this book engages with neoliberalism as a part of social reality, and thus provides nuances surrounding the complex theoretical argument that emerge within specific case-contexts involving water in its many forms. This book manages to compile different angles on the meanings, uses, rights, and politics of water in a unique way. By bringing together a broad range of topics, this book not only engages with overall questions on the rights to development and social justice, but also engaging with discourses and other theoretical lenses, such as political economy, thinking and working politically, feminist political ecology, and the political economy of informality.

Second, considering the extensive topics and debates, this book remains extremely accessible, managing to avoid complicated academic jargon while explaining a constellation of key issues that matter most. This also provides advantages to the non-water specialists or academics and practitioners interested in accessing the book in meaningful ways.

The book is well-structured, easy to follow, and insightful in terms of the varied ontological approaches, case studies, and analytical frameworks used. Future works on different regional or topical engagement, such as in the Asia-Pacific context, and various social phenomenon would add greater compass to the book's messages, particularly if follow up work could take up questions across emerging-megacities, peri-urban or de-urbanization contexts. Greater attention could also be devoted to the notions of flexibilization (Fraser, 2003), particularly in the increasing precarity of society-nature-technology relations around mobility and everyday life, particularly during the Covid19 pandemic. How water, in its multifaceted forms, plays a crucial role in exacerbating or reducing 
vulnerabilities will only continue to grow in terms of its overall relevance in theoretical and policy debates. Several social contexts that are crucial to be discussed for future projects, also include for instance, post-war contexts, armed conflict, and statelessness, which also highlight the extremes of political contestation around water.

To sum up, Water Politics: Governance, Justice and the Right to Water is an important book that is also enjoyable to read. The editors, Farhana Sultana and Alex Loftus, have done a tremendous job of bringing in the many dimensions of water into a book with a clear message, namely that water will always be contested in multifaceted ways, crucial for lives in multispecies context, and thus will continue to grow in its relevance. It is key for researchers to stay strategically close to these issues, building on the methodological and empirical insights from this book to develop deeper engagement.

Conflicts of Interest: The author declares no conflict of interest.

\section{References}

Barnett, J., \& Campbell, J. (2010). Climate Change and Small Island States: Power, Knowledge and the South Pacific (1st ed.). Routledge. https://doi.org/10.4324/9781849774895

Barnett, J. (2001). The Meaning of Environmental Security: Ecological Politics and Policy in The New Security Era. Zed Books.

Bessell, S. (2015). The individual deprivation measure: Measuring poverty as if gender and inequality matter. Gender \& Development, 23(2), 223-240. https://doi.org/10.1080/13552074.2015.1053213

Fraser, N. (2003). From discipline to flexibilization? Rereading Foucault in the shadow of globalization. Constellations, 10(2), 160-171. https://doi.org/10.1111/1467-8675.00321

Fraser, N. (2009). Scales of Justice: Reimagining Political Space in A Globalizing World (Vol. 31). Columbia University Press

Kooy, M. (2014). Developing Informality: The Production of Jakarta's Urban Waterscape. Water Alternatives, 7(1), 35-53.

Kooy, M., \& Bakker, K. (2008). Technologies of government: Constituting subjectivities, spaces, and infrastructures in colonial and contemporary Jakarta. International Journal of Urban and Regional Research, 32(2), 375-391. https://doi.org/10.1111/j.1468-2427.2008.00791.x

Lahiri-Dutt, K., \& Samanta, G. (2013). Dancing with the river: people and life on the chars of South Asia. Yale University Press. https://doi.org/10.12987/yale/9780300188301.001.0001

Sultana, F. (2014). Gendering Climate Change: Geographical Insights. Professional Geographer 66(3), 372-81. https://doi.org/10.1080/00330124.2013.821730 